\title{
The Golden Age of Molecular Ecology
}

\section{Oleg Paliy*}

Department of Biochemistry and Molecular Biology, Boonshoft School of Medicine, Wright State University, Dayton, Ohio, USA

The observations of different organisms' interactions with their environment and with each other can probably be extended back to prehistoric times when humans became inquisitive about the conditions in which they lived and survived. This process became more "scientific" in Ancient Greece, when great philosophers of the time such as Aristotle, Hippocrates, and Herodotus provided first written evidence and descriptions of nature and the observable interactions among different animals and plants [1]. By now, while still a relatively young discipline, ecology has developed into a complex science that encompasses analyses of ecosystem biodiversity, spatial and temporal species distribution and dynamic fluctuation, cross-species interactions, and evolutionary processes in the environment.

While the original ecological studies have been based on direct observation, the ecological disciplines have gradually involved the use of DNA and protein sequences in the evaluation of environmental diversity, community composition, evolutionary relationships, and species taxonomy. The use of molecular analyses has seen the largest impact in two areas, those of phylogenetic and biodiversity assessments. In both cases, by utilizing the general principle of molecular sequence conservation and gradual mutation over time, we can evaluate evolutionary relationships among species as well as reveal species identities by only analyzing select few DNA (or sometimes protein) sequences from each organism. Thus, current systematics and taxonomy no longer need to rely on the observations of species morphological and physiological characteristics but can rather use molecular phylogenetic information. Similarly, ecosystem biodiversity measurements should no longer have to rely on an exhaustive description and direct detection of all ecosystem inhabitants, but can rather employ DNA analysis to reveal who is present. The latter approach is especially effective for the studies of microbial communities, where cultivating and examining separately all individual members of the community is in many cases not practical.

Thanks to the recent advances in DNA sequencing and microarray technologies we can now obtain unprecedented amount of molecular data within a single experiment. Novel "next-generation" sequencing (NGS) platforms have enabled a bloom in DNA sequence acquisition as evidenced by the near logarithmic rate of growth of sequence

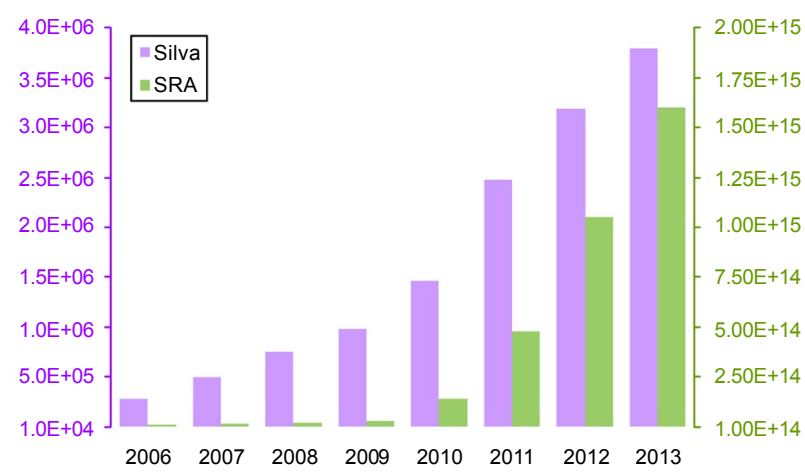

Figure 1: Expansion of DNA sequence databases in the last eight years. Figure shows the total number of small subunit ribosomal RNA gene sequences in the Silva database (left $Y$ axis, data were obtained from http://www.arb-silva.de/ documentation/release-115/) and the total number of nucleotide bases in the $\mathrm{NCBI}$ Sequence Read Archive database (right $Y$ axis, data were obtained from http://www.ncbi.nlm.nih.gov/Traces/sra/).
Table 1: Current cost and output of sample processing on selected NGS platforms and phylogenetic microarrays.

\begin{tabular}{|l|l|r|r|r|}
\hline Platform & Read length & $\begin{array}{r}\text { Price/ } \\
\text { sample }\end{array}$ & $\begin{array}{r}\text { No. of reads/ } \\
\text { sample }\end{array}$ & $\begin{array}{r}\text { Total output } \\
\text { (ncts)/sample }\end{array}$ \\
\hline \multirow{2}{*}{454 GS FLX } & $400-500$ ncts & $\$ 150$ & 10,000 & $4,500,000$ \\
\cline { 2 - 6 } & $600-1000$ ncts & $\$ 180$ & 10,000 & $7,500,000$ \\
\hline \multirow{2}{*}{ Illumina MiSeq } & $2 \times 150$ ncts & $\$ 80$ & 200,000 & $40,000,000$ \\
\cline { 2 - 6 } & $2 \times 250$ ncts & $\$ 100$ & 200,000 & $80,000,000$ \\
\hline \multirow{2}{*}{ Ion Torrent PGM } & 200 ncts & $\$ 60$ & 20,000 & $4,000,000$ \\
\cline { 2 - 6 } & 400 ncts & $\$ 100$ & 20,000 & $8,000,000$ \\
\hline Phyloarrays
\end{tabular}

*Pricing and read output information was provided by MR DNA facility, http://www mrdnalab.com

† Information is provided for Microbiota Array [5]

$\ddagger$ Conserved estimate based on the combined measured signal from all microarray probes [28]

deposition into such databases as RDP and Silva (collect small and large ribosomal subunit RNA sequences) and NCBI SRA (stores short-read sequencing data) (Figure 1). Examples of currently widely used NGS platforms include Roche 454 GS FLX system, Illumina HiSeq and MiSeq devices, Applied Biosystems SOLiD system, and Life Technologies Ion Torrent PGM machine. The costs of sequence acquisition have also been reduced tremendously, with current prices thousand fold less per nucleotide than that for the previously-standard Sanger-based sequencing (see Table 1). NGS has utilized to i) carry out whole genome sequencing including an effort to generate individual human genome sequence for under $\$ 1,000$ [2], to ii) evaluate evolutionary relationships among organisms, to iii) reveal allele variants and epigenetic status in populations, to iv) assess cell-wide gene expression levels (RNA-Seq), and to v) determine gene essentiality with genome-wide transposon mutagenesis (Tn-Seq) [3]. The use of NGS approach to directly sample DNA composition from a complex environment allows detection of novel and previously unrecognized members (ribosomal RNA interrogation) and it provides means to assess functional diversity and metabolic capacity in many ecosystems and environments (metagenomics and metatranscriptomics). High-density phylogenetic microarrays, another recently developed platform, contain probes complementary to the small subunit rRNA gene sequences of many different community members. Because each individual array of particular design contains the same set of probes, environmental DNA interrogation with phyloarrays provides high-throughput quantitation of each species abundance in each sample [4]. Currently available phylogenetic microarrays have been developed based on Affymetrix GeneChip design [5], Agilent platform [6], or coated glass slides [7].

While many recent studies have taken advantage of the availability

*Corresponding author: Oleg Paliy, PhD, 260 Diggs Laboratory, Wright State University, 3640 Col. Glenn Hwy, Dayton, OH 45435, USA, Fax: (1) 937-775-3730; E-mail: oleg.paliy@wright.edu

Received June 25, 2013; Accepted June 28, 2013; Published July 01, 2013

Citation: Paliy O (2013) The Golden Age of Molecular Ecology. J Phylogen Evolution Biol 1: e105. doi:10.4172/2329-9002.1000e105

Copyright: (c) 2013 Paliy O. This is an open-access article distributed under the terms of the Creative Commons Attribution License, which permits unrestricted use, distribution, and reproduction in any medium, provided the original author and source are credited. 
of these high-throughput technologies [8], the most significant advances have occurred in the area of microbial ecology. Many of such studies sought to provide biodiversity and phylogenetic analyses of environmentally derived samples from a variety of ecosystems including marine, freshwater, wetlands, soil, sewage, and of microbial communities associated with plants and animals. For example, Marine Microbial Genome Sequencing project aimed to sequence full genomes of 165 marine microbes (http://camera.calit2.net/microgenome/), Sargasso Sea Sequencing project provided a snapshot of functional gene diversity in ocean plankton [9], and Gilbert and colleagues assessed seasonal dynamics in the composition of microbial communities in the Western English Channel [10]. The analyses of soil ecosystems determined microbial community structure and functional repertoire of grasslands and forests [11,12], and have examined the relationships between plant roots and soil microbes [13] as well as the resistance of these ecosystems to invading pathogens [14]. Investigations of the interactions between plants and leaf surface microbes revealed paths of bacterial succession during seasonal changes [15] and geographical and phylogenetic variability in the distribution of plant-associated microbial species [16]. A large number of reports on human-associated microbes was also made available, which revealed that microbiota dysbiosis can be linked to a number of human diseases including psoriasis, atopic dermatitis, bacterial vaginosis, dental plaque, inflammatory bowel disease, obesity, and colon cancer (reviewed by Sekirov and colleagues [17]). Current large-scale NGS-based initiatives include Earth Microbiome Project [18] that will analyze 200,000 samples collected from diverse earth environments (ocean, sand, soil, and so forth), and Human Microbiome Project [19] and MetaHIT [20] that aim to understand diversity and complexity of microbial communities associated with humans.

At the same time, phylogenetic microarrays have also been successfully used to quantitatively profile a variety of ecosystem communities, mostly those of microbial origin from the human gastrointestinal tract, ocean waters, sewage sludge, soil, and air [7,21,22]. Specific examples include investigations of ecosystem impact by the oil plumes released during the Deep Horizon oil spill [23], of the effect of soil contamination with trichloroethylene on the soil microbiome [7], and of the microbiota of the human gut of children [24-26].

The recent introduction and current advances in high-throughput sequencing and microarray platforms have generated a tremendous level of excitement among many molecular ecologists. The rapidly increasing ease and decreasing costs of sequence acquisition mean that we can now obtain millions and billions of nucleotide sequences in a single experiment. All of these data are available for analysis and interpretation, and the next step is to develop new and improved analytical approaches to derive biologically relevant insights based on the acquired sequences. By utilizing these large datasets, complex mathematical models of species interactions and ecosystem dynamics can also be created $[27,28]$. Such models would allow not only in silico based predictions of community responses to perturbations, but can also reveal underlying mechanisms of ecosystem behavior and dynamics. Molecular ecology can truly be considered to have entered its golden age.

\section{References}

1. Egerton FN (2001) A history of the ecological sciences: early Greek origins Bulletin of the Ecological Society of America 82: 93-97.

2. Kedes L, Campany $G$ (2011) The new date, new format, new goals and new sponsor of the Archon Genomics X PRIZE competition. Nat Genet 43:10551058.

3. Kamb A (2011) Next-generation sequencing and its potential impact. Chem Res Toxicol 24: 1163-1168.
4. Paliy O, Agans R (2012) Application of phylogenetic microarrays to interrogation of human microbiota. FEMS Microbiol Ecol 79: 2-11.

5. Paliy O, Kenche H, Abernathy F, Michail S (2009) High-throughput quantitative analysis of the human intestinal microbiota with a phylogenetic microarray. Appl Environ Microbiol 75: 3572-3579.

6. Rajilic-Stojanovic M, Heilig HG, Molenaar D, Kajander K, Surakka A, et al (2009) Development and application of the human intestinal tract chip, a phylogenetic microarray: analysis of universally conserved phylotypes in the abundant microbiota of young and elderly adults. Environ Microbiol 11: 17361751.

7. Nemir A, David MM, Perrussel R, Sapkota A, Simonet P, et al. (2010) Comparative phylogenetic microarray analysis of microbial communities in TCE-contaminated soils. Chemosphere 80: 600-607.

8. Lister R, Gregory BD, Ecker JR (2009) Next is now: new technologies for sequencing of genomes, transcriptomes, and beyond. Curr Opin Plant Biol 12 107-118.

9. Venter JC, Remington K, Heidelberg JF, Halpern AL, Rusch D, et al. (2004) Environmental genome shotgun sequencing of the Sargasso Sea. Science 304: 66-74.

10. Gilbert JA, Steele JA, Caporaso JG, Steinbruck L, Reeder J, et al. (2012) Defining seasonal marine microbial community dynamics. Isme J 6: 298-308.

11. Delmont TO, Prestat E, Keegan KP, Faubladier M, Robe P, et al. (2012) Structure, fluctuation and magnitude of a natural grassland soil metagenome. Isme J 6: 1677-1687.

12. Baldrian P, Kolarik M, Stursova M, Kopecky J, Valaskova V, et al. (2012) Active and total microbial communities in forest soil are largely different and highly stratified during decomposition. Isme J 6: 248-258.

13. Bulgarelli D, Rott M, Schlaeppi K, Ver Loren van Themaat $E$, Ahmadinejad $\mathrm{N}$, et al. (2012) Revealing structure and assembly cues for Arabidopsis rootinhabiting bacterial microbiota. Nature 488: 91-95.

14. van Elsas JD, Chiurazzi M, Mallon CA, Elhottova D, Kristufek V, et al. (2012) Microbial diversity determines the invasion of soil by a bacterial pathogen. Proc Natl Acad Sci USA 109:1159-1164.

15. Redford AJ, Fierer N (2009) Bacterial succession on the leaf surface: a nove system for studying successional dynamics. Microb Ecol 58: 189-198.

16. Redford AJ, Bowers RM, Knight R, Linhart Y, Fierer N (2010) The ecology of the phyllosphere: geographic and phylogenetic variability in the distribution of bacteria on tree leaves. Environ Microbiol 12: 2885-2893.

17. Sekirov I, Russell SL, Antunes LC, Finlay BB (2010) Gut microbiota in health and disease. Physiol Rev 90: 859-904.

18. Gilbert JA, Meyer F (2012) Modeling the Earth Microbiome. Microbe 7: 64-69.

19. NIH HMP Working Group, Peterson J, Garges S, Giovanni M, Mclnnes P, et al. (2009) The NIH Human Microbiome Project. Genome Res 19: 2317-2323.

20. Qin J, Li R, Raes J, Arumugam M, Burgdorf KS, et al. (2010) A human gut microbial gene catalogue established by metagenomic sequencing. Nature 464: 59-65.

21. Brodie EL, DeSantis TZ, Parker JP, Zubietta IX, Piceno YM, et al. (2007) Urban aerosols harbor diverse and dynamic bacterial populations. Proc Natl Acad Sci U SA 104: 299-304.

22. Agans R, Rigsbee L, Kenche H, Michail S, Khamis HJ, et al. (2011) Distal gut microbiota of adolescent children is different from that of adults. FEMS Microbiol Ecol 77: 404-412.

23. Hazen TC, Dubinsky EA, DeSantis TZ, Andersen GL, Piceno YM, et al. (2010) Deep-sea oil plume enriches indigenous oil-degrading bacteria. Science 330 204-208.

24. Rigsbee L, Agans R, Shankar V, Kenche H, Khamis HJ, et al. (2012) Quantitative profiling of gut microbiota of children with diarrhea-predominant irritable bowel syndrome. Am J Gastroenterol 107: 1740-1751.

25. Shankar V, Agans R, Holmes B, Raymer M, Paliy O (2013) Do gut microbial communities differ in pediatric IBS and health? Gut Microbes 4: 1-6.

26. Ringel-Kulka T, Cheng J, Ringel Y, Salojärvi J, Carroll I, et al. (2013) Intestina microbiota in healthy U.S. young children and adults-a high throughput microarray analysis. PLoS One 8: e64315. 
27. Larsen PE, Gibbons SM, Gilbert JA (2012) Modeling microbial community structure and functional diversity across time and space. FEMS Microbiol Lett 332: $91-98$.
28. Rigsbee L, Agans R, Foy BD, Paliy O (2011) Optimizing the analysis of human intestinal microbiota with phylogenetic microarray. FEMS Microbiol Ecol 75: 332-342. 